\title{
Індукція імунної толерантності: стандарт лікування інгібіторної форми гемофілії
}

\section{К.В. Вільчевська}

Національна дитяча спеціалізована лікарня «Охматдит», Київ, Україна

ДУ «Інститут невідкладної та відновної хірургії імені В.К. Гусака НАМН України», Київ, Україна

Сьогодні розвиток інгібіторної форми гемофілії (ІФГ) — одна 3 найбільших проблем у лікуванні пацієнтів із гемофілією. Елімінація інгібіторів шляхом проведення терапії за методом індукції імунної толерантності (IIT) - перша лінія терапії у пацієнтів з інгібітором. Цей метод полягає у частому призначенні високих доз концентрату фактора згортання, щоб привчити організм приймати лікування без реакції на нього [1, 2]. Більшість хворих стають толерантними протягом 12 міс, але у більш резистентних випадках може знадобитися $\geq 2$ років (рис. 1). Традиційний підхід IIT при менеджменті пацієнтів з ІФГ полягає у тому, що перед проведенням IIT необхідно чекати <2 років до зниження титру інгібітора <10 БО, за умови відсутності тяжких кровотеч у пацієнта. Однак результати дослідження A. Rocino та співавторів (2016) продемонстрували, що, по-перше, час до початку IIT $\epsilon$ важливішим, ніж величина самого титру на початку IIT, та, по-друге, відсутність зв'язку між титром інгібітора та початком IIT [3]. Отримані результати спростували ефективність традиційного підходу до IIT. У 2017 р. оприлюднені рекомендації Організації лікарів Центру гемофілії Великобританії (The United Kingdom Haemophilia Centre Doctors' Organisation —
UKHCDO) щодо менеджменту пацієнтів із гемофілією, в яких зазначено, що, відповідно до сучасного підходу, IIT рекомендовано починати якомога швидше, незалежно від титру інгібітора (рис. 2) [4].

Можливості елімінації інгібітора вивчають протягом багатьох років. Сьогодні наявні декілька протоколів терапії (табл. 1). Загальної думки з питання оптимального дозування і частоти доз при IIT не існує; зараз проводяться міжнародні дослідження, щоб порівняти результати застосування 50 МО і 200 МО. Дані літератури свідчать, що найбільшого поширення набули дві схеми IIT: низько- та високодозовий протоколи, але дані попередніх досліджень про відносну ефективність цих схем досить суперечливі, що пов'язано з тим, що в дослідженнях застосовували різні критерії ефективності, аналізовані групи були еквівалентними й використовували різні підходи до терапії. Крім того, при аналізі результатів ефективності протоколів IIT важливо враховувати фактори, що впливають на ї̈ ефективність.

Фактори, що впливають на результат IIT:

- Загальноприйняті фактори успішної ІІT:

- історичний пік титру інгібітора <200 БО;

Рисунок 1 Успішна IIT
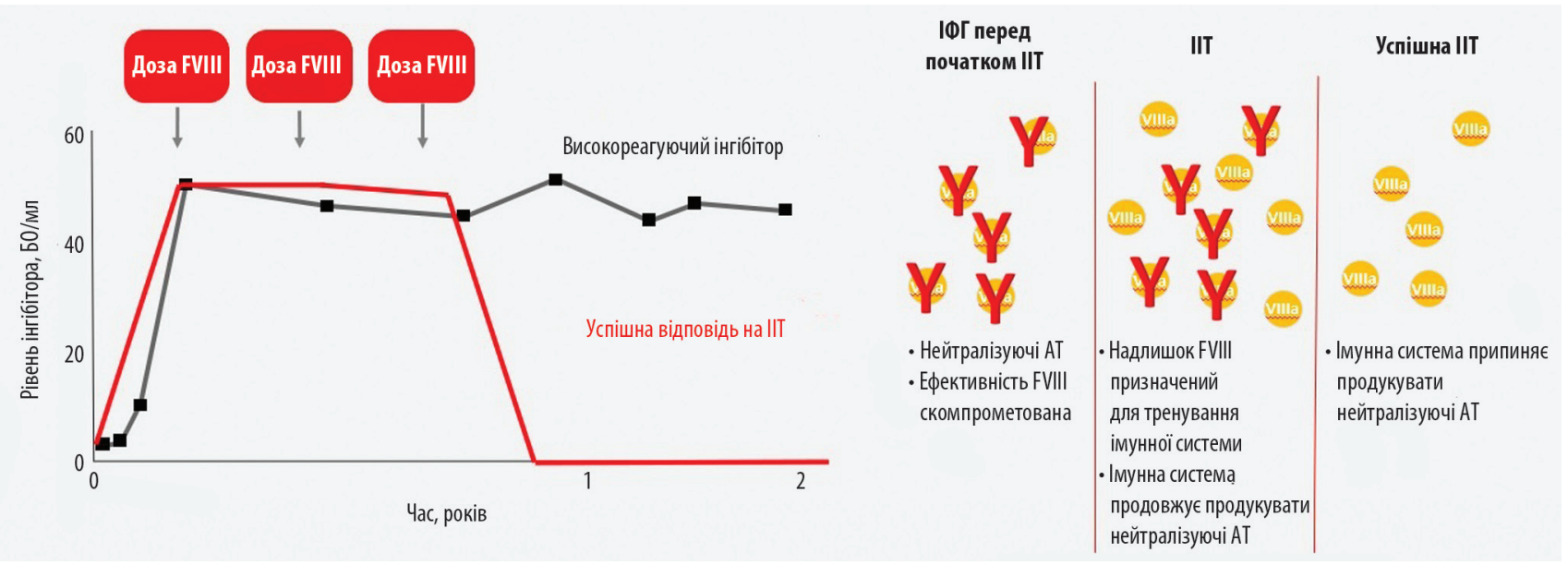

Б0 — Бетезда одиниці; АТ — антитіла.

Рисунок 2 Алгоритм ерадикації інгібітора шляхом IIT

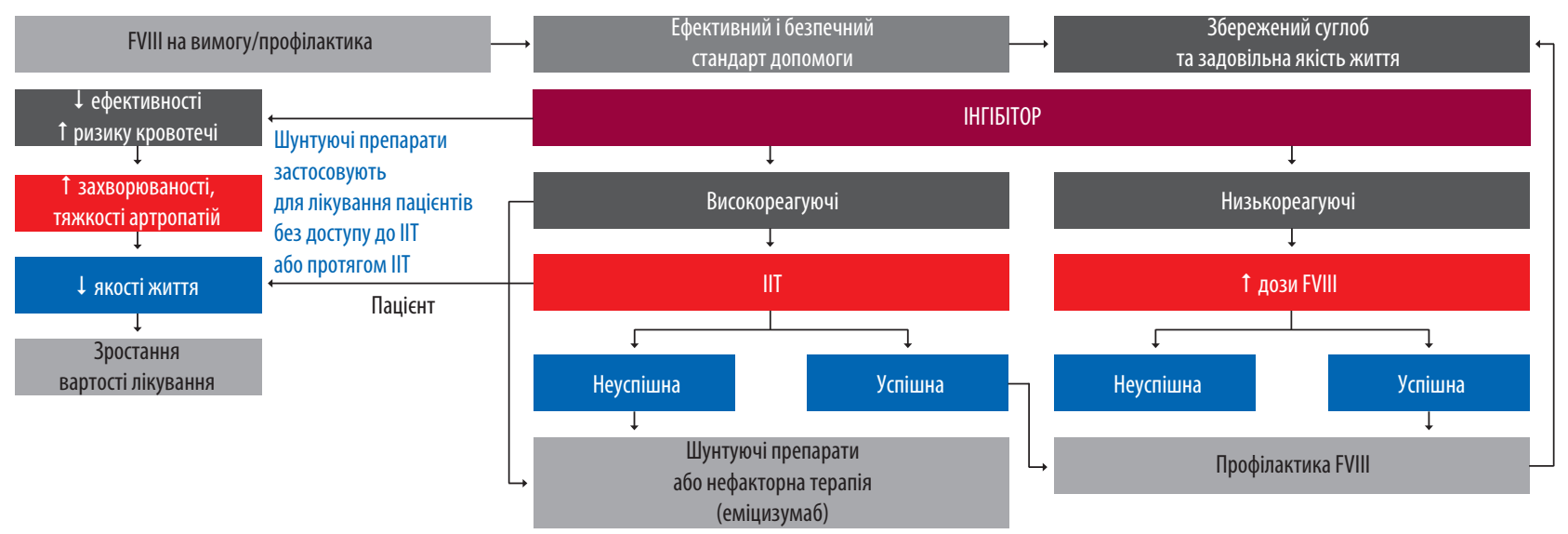


- титр інгібітора на момент початку ІІТ <10 БО.

- Опосередковані фактори успішної IIT:

- початок у віці < 6 років;

- початок протягом 2 років з моменту розвитку інгібітора.

- Несприятливий фактор проведення IIT:

- підвищення титру інгібітора >500 БО після початку IIT.

3 урахуванням цих факторів, дані дослідження C.E. Ettingshausen та W. Kreuz (2013) дозволили зробити висновок, що у пацієнтів із прогностичними факторами успішної IIT наявний позитивний результат щодо елімінації інгібітора, незалежно від вибраного протоколу [5]. Також виявлено, що низькодозовий протокол IIT $\epsilon$ більш тривалим за часом і має вищу частоту геморагічних епізодів порівняно з високодозовим протоколом. Ці висновки свідчать на користь того, що у пацієнтів із несприятливими прогностичними факторами перевага має віддаватися високодозовому протоколу IIT.

Рекомендації щодо моніторингу титру інгібітора в ході IIT:

- на початку IIT титр інгібітора необхідно визначати щотижнево для виявлення піка інгібітора, потім - щомісячно для оцінки відповіді на IIT;

- при аналізі Бетезда в модифікації Ніймегена не використовувати період відмивки;

- зниження титру інгібітора як мінімум на 20\% кожні 6 міс після досягнення піка свідчить про розвиток толерантності й не потребує змін у терапії;

- після зниження титру інгібітора <0,6 БО/мл визначення титру інгібітора слід повторювати кожні 3 міс у період до 2 років після закінчення IIT, потім - щорічно.

Рекомендації щодо моніторингу титру інгібітора після закінчення IIT:

- моніторинг інгібітора в тесті Бетезда та визначення залишкової активності FVIII проводиться щомісячно протягом 6 міс, потім — кожні 2 міс протягом року, потім у рутинному порядку;

- при рецидиві інгібітора рекомендовано негайне відновлення IIT.

Відповідно до сучасних рекомендацій, IIT вважають успішною тоді, коли досягнуті такі показники: персистуючий титр інгібітора $<0,6$ БО/мл, активність відновлення FVIII $\geq 66 \%$, час напіввиведення FVIII $\geq 6$ год у дорослих та $\geq 7$ год у дітей. Рішення про зупинку IIT повинно бути прийняте, коли титр інгібітора не підвищувався $\geq 20 \%$ у межах 9 міс від початку лікування чи досягнута хоча 6 часткова відповідь на лікування у межах 33 міс [6, 7] (табл. 2).

Таким чином, IIT — перша лінія терапії у пацієнтів з ІФГ, яка забезпечує елімінацію інгібітора. Однак, незважаючи на ефективність IIT, цей метод демонструє неефективність у $30 \%$ випадків. Крім того, IIT пов'язана з низкою недоліків, включно з потребою у постійному венозному доступі та інфекціями, асоційованими із засобами центрального венозного доступу, прихильністю паці$\epsilon$ нтів до лікування та доступністю препарату фактора згортання. Останн $\epsilon$ зумовило недостатнє застосування ІІT у більшості країн, зокрема і в Україні, що пов'язано з недостатнім забезпеченням факторами згортання крові на душу населення. За даними Громадської організації інвалідів «Всеукраїнське товариство гемофілії», до 2017 р. рівень забезпечення VIII фактором згортання крові в Україні становив 0,8 Од./рік на душу населення, тоді як, згідно з нормами Всесвітньої федерації гемофілії (World Federation of Hemophilia - WFH), для забезпечення виживаності пацієнтів із гемофілією необхідний рівень не нижчий 1 Од./рік. Відповідно,

\section{Відомості про автора:}

Вільчевська Катерина Вікторівна — кандидат медичних наук, завідувач Центру патології гемостазу Національної дитячої спеціалізованої лікарні «0хматдит», завідувач центру патології гемостазу ДУ «Інститут невідкладної та відновної хірургії імені В.К. Гусака НАМН України», Київ, Україна. Адреса для кореспонденції:

Вільчевська Катерина Вікторівна

01135, м. Київ, вул. Шолуденка, 10

E-mail:dr.vilchevska@gmail.com
Таблиця 1 ІІТ-протоколи терапії при гемофілії A

\begin{tabular}{|c|c|}
\hline \multicolumn{2}{|r|}{ IIT-протоколи терапії при гемофілії А } \\
\hline Протокол & Доза \\
\hline Бонський протокол/ & 100-150 M0 FVIII/кг маси тіла кожні 12 год \\
\hline високодозовий & $\begin{array}{l}\text { Супутнє лікування із застосуванням препаратів із шунтуючим } \\
\text { механізмом дії (аРСC або rFVIIla двічі на добу), відповідно } \\
\text { до тенденції кровотеч }\end{array}$ \\
\hline Високодозовий & 200 M0 FVIII/кг кожні 24 год \\
\hline Середньодозовий & 100 M0 FVIII/кг щоденно \\
\hline $\begin{array}{l}\text { van Creveld (голланд- } \\
\text { ський)/низькодозовий }\end{array}$ & 25-50 M0 FVIII/кг через день \\
\hline
\end{tabular}

aPCC — антиінгібіторний коагуляційний комплекс; rFVIla — рекомбінантний активований FVII.

Таблиця 2 Варіанти можливих результатів IIT

\begin{tabular}{|c|c|}
\hline \multicolumn{2}{|r|}{ Результати IIT } \\
\hline Ефективність & Значення показника \\
\hline Успішна IIT & $\begin{array}{l}\text { Критерії успішної ІІІ: } \\
\text { - титр інгібітора <0,6Б0/мл (виявлений у } \geq 2 \text { послідовних дослідженнях) } \\
\text { - нормалізація показника відновлення: } \geq 66 \% \text { протягом } \geq 2 \text { міс } \\
\text { - нормалізація періоду напіввиведення: }>6 \text { год }\end{array}$ \\
\hline Частковий успіх IIT & Наявні 2 із 3 критеріїв успішної IIT \\
\hline Часткова відповідь & Наявний 1 із 3 критеріїв успішної IIT \\
\hline Відсутня відповідь & Немає жодного із критеріїв успішної IIT протягом $\geq 12$ міс \\
\hline
\end{tabular}

за неможливості проведення чи неефективності IIT, профілактику кровотеч рекомендовано проводити препаратом нефакторної терапії (еміцизумаб) або препаратами із шунтуючим механізмом дії, такими як аPCC або rFVIIa, зокрема як супровід IIT [8].

За підтримки ТОВ «Такеда Україна» VV-MEDMAT-37035

\section{Список використаної літератури/References:}

1. Brackmann H-H., White G.C. ${ }^{\text {nd }}$, Berntorp E. et al. (2018) Immune tolerance induction: What have we learned over time? Haemophilia, 24(Suppl. 3): 3-14. doi: 10.1111/hae.13445

2. Bruinstroop E., Klok F.A., Van De Ree M.A. et al. (2009) Elevated D-dimer levels predict recurrence in patients with idiopathic venous thromboembolism: a meta-analysis. J. Thromb. Haemost., 7(4): 611-618. doi: 10.1111/j.1538-7836.2009.03293.x

3. Rocino A., Cortesi P.A., Scalone L. et al. (2016) Immune tolerance induction in patients with haemophilia a and inhibitors: effectiveness and cost analysis in an European Cohort (The ITER Study. Haemophilia, 22(1): 96-102. doi: 10.1111/hae.12780

4. Collins P., Chalmers E., Alamelu J. et al. (2017) First-line immune tolerance induction for children with severe haemophilia A: A protocol from the UK Haemophilia Centre Doctors' Organisation Inhibitor and Paediatric Working Parties. Haemophilia, 23(5): 654-659. doi: 10.1111/hae. 13264

5. Ettingshausen C.E., KreuzW. (2013) The immune tolerance induction (ITI) dose debate: does the International ITI Study provide a clearer picture? Haemophilia, 19(Suppl. 1): 12-17. doi: 10.1111/hae. 12051

6. Hay C.R.M., DiMichele D.M., International Immune Tolerance Study (2012) The principal results of the International Immune Tolerance Study: a randomized dose comparison. Blood, 119(6): 1335-1344. doi: 10.1182/blood-2011-08-369132

7. Valentino L.A., Kempton C.L., Kruse-Jarres R. et al. (2015) US Guidelines for immune tolerance induction in patients with haemophilia a and inhibitors. Haemophilia, 21(5): 559-567. doi: 10.1111/hae. 12730

8. Vilchevska K.V. (2020) Experience of the early treatment in patients with inhibitory form of hemophilia A in conditions of limited resources. UMJ, 6(140), V. 1: 55-58 (In Ukr.).

\section{Information about the author:}

Vilchevska Kateryna V. - Candidate of Medical Sciences, Head of the Center of hemostasis pathology of the National Children Special Hospital «Ohmatdet», Head of the Center of hemostasis pathology of the V.K. Gusak Institute of Urgent and Recovery Surgery of NAMS of Ukraine, Kyiv, Ukraine.

Address for correspondence:

Kateryna Vilchevska

01135, Kyiv, Sholudenko str., 10

E-mail:dr.vilchevska@gmail.com 
ТЕСТОВІ ЗАПИТАННЯ

(один або декілька правильних варіантів відповідей на кожне запитання)

1. Визначте фактори, пов'язані з успішною IIT:

$\square$ історичний пік титру інгібітора $<200$ БО

$\square$ історичний пік титру інгібітора $<50$ БО

$\square$ титр інгібітора на момент початку IIT <10 БО

$\square$ титр інгібітора на момент початку IIT >20 БО

2. До несприятливих факторів проведення ІІТ відноситься:

$\square$ підвищення титру інгібітора >500 БО після початку IIT

$\square$ зниження титру інгібітора $<10$ БО

$\square$ зниження титру інгібітора < 0,6 БО/мл

$\square$ усі відповіді вірні

3. Визначте критерії успішної ІІт:

$\square$ титр інгібітора $<0,6$ БО/мл

$\square$ нормалізація показника відновлення $\geq 66 \%$ протягом $\geq 2$ міс

$\square$ нормалізація періоду напіввиведення $>6$ год

$\square$ титр інгібітора $>0,6$ БО/мл

4. Часткова відповідь на IIT визначається при наявності:

$\square 133$ критеріїв успішної ІІT

$\square$ усіх трьох критеріїв успішної IIT

2 з 3 критеріїв успішної IIT

$\square$ відсутності жодного з критеріїв успішної ІІT

5. Високодозовий протокол IIT характеризується:

введенням FVIII/кг у дозі $200 \mathrm{MO}$ $\square$ введенням FVIII/кг у дозі 25-50 MO

$\square$ введенням FVIII/кг у дозі <100 MO

$\square$ усі відповіді вірні

6. Який із протоколів ІІТ передбачає застосування препаратів із шунтуючим механізмом дії?

$\square$ Бонський протокол/високодозовий

$\square$ середньодозовий протокол

$\square$ низькодозовий протокол

$\square$ усі відповіді вірні

7. 3 якою частотою рекомендовано проводити моніторинг інгібітора на початку IIT?
$\square$ щотижнево
$\square$ щоденно
$\square$ щомісячно
$\square$ кожні 2 год

8. 3 якою частотою рекомендовано проводити моніторинг інгібітора після закінчення IIT?

$\square$ щомісячно протягом перших 6 міс, далі кожні 2 міс протягом року, далі в рутинному порядку

$\square$ щотижнево протягом 1-го року, далі в рутинному порядку

$\square$ щомісячно протягом перших 2-х років

$\square$ усі відповіді вірні

\section{Для отримання сертифіката дайте відповідь на тестові запитання в режимі on-line на сайті журналу www.umj.com.ua або надішліть ксерокопію сторінок з відповідями разом з контактною інформацією за адресою: 01001, Київ-1, a/c «B»-82, ТОВ «МОРІOH»}

ПІБ

Поштова адреса: індекс
область
район
місто
вулиця
будинок
квартира

Tелефон
E-mail

